\title{
Hard amorphous hydrogenated carbon films deposited from an expanding thermal plasma
}

\section{Citation for published version (APA):}

Gielen, J. W. A. M., Sanden, van de, M. C. M., Kessels, W. M. M., Kleuskens, P. R. M., Zande, van der, M. J., \& Schram, D. C. (1996). Hard amorphous hydrogenated carbon films deposited from an expanding thermal plasma. In Extended abstracts of the Carbon '96 : European Carbon Conference, 7-12 July 1996, University of Newcastle upon Tyne (Vol. 2, pp. 409-410)

Document status and date:

Published: 01/01/1996

\section{Document Version:}

Publisher's PDF, also known as Version of Record (includes final page, issue and volume numbers)

\section{Please check the document version of this publication:}

- A submitted manuscript is the version of the article upon submission and before peer-review. There can be important differences between the submitted version and the official published version of record. People interested in the research are advised to contact the author for the final version of the publication, or visit the $\mathrm{DOI}$ to the publisher's website.

- The final author version and the galley proof are versions of the publication after peer review.

- The final published version features the final layout of the paper including the volume, issue and page numbers.

Link to publication

\section{General rights}

Copyright and moral rights for the publications made accessible in the public portal are retained by the authors and/or other copyright owners and it is a condition of accessing publications that users recognise and abide by the legal requirements associated with these rights.

- Users may download and print one copy of any publication from the public portal for the purpose of private study or research.

- You may not further distribute the material or use it for any profit-making activity or commercial gain

- You may freely distribute the URL identifying the publication in the public portal.

If the publication is distributed under the terms of Article 25fa of the Dutch Copyright Act, indicated by the "Taverne" license above, please follow below link for the End User Agreement:

www.tue.nl/taverne

Take down policy

If you believe that this document breaches copyright please contact us at:

openaccess@tue.nl

providing details and we will investigate your claim. 


\title{
HARD AMORPHOUS HYDROGENATED CARBON FILMS DEPOSITED FROM AN EXPANDING THERMAL PLASMA
}

\author{
J.W.A.M. Gielen ${ }^{*}$, M.C.M. van de Sanden, W.M.M. Kessels, P.R.M. Kleuskens, M.J. van der Zande \\ and D.C. Schram \\ Eindhoven University of Technology, Department of Physics, PO Box 513, 5600 MB Eindhoven, The Netherlands
}

\section{INTRODUCTION}

Amorphous hydrogenated carbon (a-C:H) is a non-crystalline form of carbon containing a certain fraction of hydrogen. It is generally produced via a Plasma Enhanced Chemical Vapour Deposition (PECVD) technique. The properties of the films may be adjusted by variation of the plasma deposition parameters and may vary from softpolymerlike to hard-diamondlike. The C-C bonding types, i.e. the $\mathrm{sp}^{2}$ and $\mathrm{sp}^{3}$ bonds, determine the actual properties. The $\mathrm{sp}^{3}$ bonds are responsible for the beneficial mechanical properties, which are for diamondlike films: high hardness $(10-20 \mathrm{GPa})$ and high elastic modulus, low friction, chemical inertness and transparency to infrared light. The optical and electronic properties are mainly due to the $\mathrm{sp}^{2}$ bonded carbon sites, which decrease the optical bandgap by enhanced cluster formation. Possible applications of a-C:H films are protective- and anti-reflection coatings on glass plates in e.g. bar-code laser scanner devices or in flat panel displays ${ }^{1}$.

The deposition of a-C:H is performed by several PECVD techniques ${ }^{2}$. All techniques have in common that a substrate bias of at least $50 \mathrm{~V}$ per deposited carbon atom is needed to obtain diamondlike properties ${ }^{1}$. In this contribution it will shown that good quality a-C:H material with comparable properties can be deposited without any external substrate bias, applying an expanding thermal plasma, and this at increasing growth rate. Furthermore, it will be shown how optimisation of the film quality is obtained and what this means for the plasma composition.

\section{EXPERIMENTAL}

The a-C:H films are deposited via an expanding thermal plasma. The set-up consists of a $\mathrm{DC}$ arc in which an argon plasma (flow $=100 \mathrm{scc} / \mathrm{s}$, pressure $=0.5 \mathrm{bar}$, electron density $\approx 10^{22} \mathrm{~m}^{-3}$, electron temperature $\approx 1 \mathrm{eV}$ ) is created. This plasma expands into a chamber at low pressure $(0.25 \mathrm{mbar})$ where the electron density and temperature in pure argon decrease to $\approx 10^{19} \mathrm{~m}^{-3}$ and $\approx 0.2 \mathrm{eV}$, respectively. Acetylene is admixed in the expansion zone. The films are deposited on glass and crystalline silicon samples at low temperature $\left(\leq 100^{\circ} \mathrm{C}\right)$ and their thickness is typically $2 \mu \mathrm{m}$. Two piasma parameters are varied. The electrical current through the plasma source is changed from 20 to $88 \mathrm{~A}$. This implies that the ionisation degree of the argon flow varies from 5 to $25 \%$. Also the admixed acetylene flow is varied from 2 to $20 \mathrm{scc} / \mathrm{s}$. An extensive description of this deposition technique is given elsewhere ${ }^{3}$.

\section{RESULTS}

Analysis of the films is performed ex-situ ${ }^{4}$. The hardness is measured via Nano-indentation, the optical bandgap via broadband visible light transmission experiments, the refractive index, thickness and $\mathrm{C}-\mathrm{H}$ bonding structure via infrared absorption spectroscopy and the total hydrogen density is obtained via Elastic Recoil Detection Analysis (ERDA). In Figure 1 the properties are given as a function of the determined infrared refractive index. It is observed that all properties are well correlated to this refractive index. The film quality, which is given by its hardness, changes from soft-polymerlike $(4 \mathrm{GPa})$, at low refractive index, to hard diamondlike (13 GPa), at higher indices. The maximum observed hardness of $13 \mathrm{GPa}$ is in the range known for diamondlike material ${ }^{1}$. However, note that for our film deposition no external substrate bias is applied. The $\mathrm{sp}^{2} / \mathrm{sp}^{3}$ ratio, from infrared spectroscopy, is found to increase at higher refractive indices. This

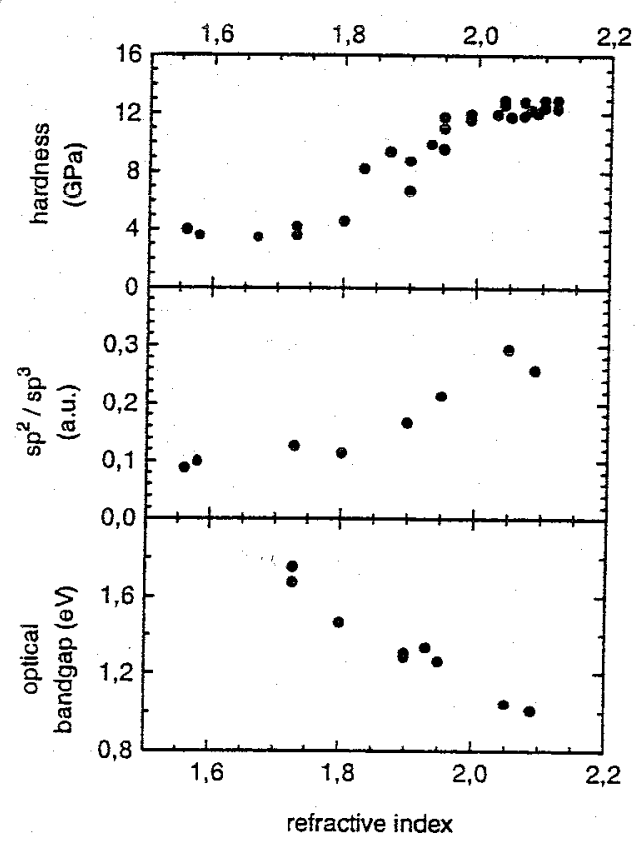

Figure 1 : The hardness, $\mathrm{sp}^{2} / \mathrm{sp}^{3}$ ratio and optical bandgap vs. the infrared refractive index. 
is probably due to an enhanced cluster formation of $\mathrm{sp}^{2}$ bonded carbon into aromatic rings ${ }^{3}$. A consequence of this is a decrease of the optical bandgap, which indeed is observed. Comparison of our film properties with other PECVD deposited diamondlike a-C:H shows that they are similar.

From Figure 1 it is obvious that quality improvement (read: hardness increment) is equivalent to maximisation of the refractive index. In Figure 2 the refractive index is given as a function of the two varied plasma parameters. A similar behaviour of the refractive index is observed at a fixed arc current: the refractive index increases with increasing acetylene admixture until a maximum, then a decrease occurs. The maximum value for each arc current is found when the admixed acetylene flux is of similar

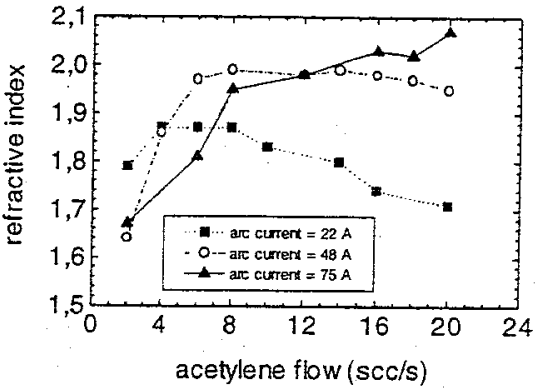

Figure $2:$ The refractive index vs. the acetylene flow at various arc currents. magnitude as the argon ion flux emanating from the plasma source. The dissociation of acetylene is believed to occur via a charge exchange reaction with an argon ion (electron induced processes are unlikely due to the low electron temperature), followed by a fast dissociative recombination with an electron, resulting in various hydrocarbon radicals $\left(\mathrm{C}_{2} \mathrm{H}, \mathrm{C}_{2}, \mathrm{CH}\right.$, etc.). When the admixed acetylene flux is smaller then the argon ion flux (underloading), the formed radicals may be dissociated again before deposition. In the case of overloading not all acetylene molecules can be dissociated, resulting in either clustering or direct deposition. Both overloading and underloading are obvious bad for film quality. The best film quality is obtained in the case of critical loading: the admixed acetylene flux equals approximately the argon ion flux.

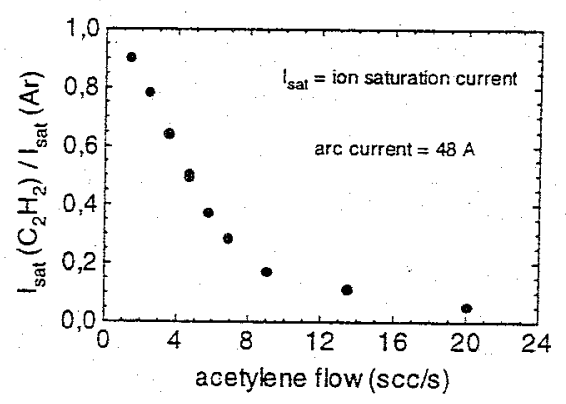

Figure 3 : The ratio of the ion saturation current in argon/acetylene and pure argon vs. the acetylene flow.
When the admixed acetylene flow increases, the argon ion density in the expansion zone is expected to decrease. Via Langmuir probe measurements the argon ion density is determined in the argon/acetylene environment. Measurement of a complete probe characteristic (current [I] - voltage [V]) is impossible as deposition of a-C:H, which is insulating, also modifies the probe surface and thus the I-V characteristic. Therefore, a measuring method is developed in which only the ion saturation current is measured ${ }^{5}$. This current is determined both in an argon/acetylene and a pure argon plasma (used as normalising reference), ensuring that for both plasma conditions the probe is identical. The ratio of both currents is a measure for the relative argon ion density in the plasma. In Figure 3 this ratio is given as a function of the admixed acetylene flow for one fixed arc current. The probe is positioned at $25 \mathrm{~cm}$ from the acetylene injection

point. It is observed that the measured ratio decreases at increasing acetylene flow, showing that more argon ions have been used to dissociate acetylene. The mean free path for the argon ions to react with acetylene is about $20 \mathrm{~cm}$. For the used arc current the argon ion flux emanating from the arc is about $10 \mathrm{scc} / \mathrm{s}$. At $10 \mathrm{scc} / \mathrm{s}$ acetylene flow admixture, more than $90 \%$ of the argon ions are lost. Thus enhanced dissociation of acetylene then is excluded. This also confirms the observed critical loading behaviour.

Finally, if the quality (read: hardness) of the films is plotted as a function of the growth rate (Figure 4) a very remarkable result is obtained: the hardness increases at higher growth rate !!!

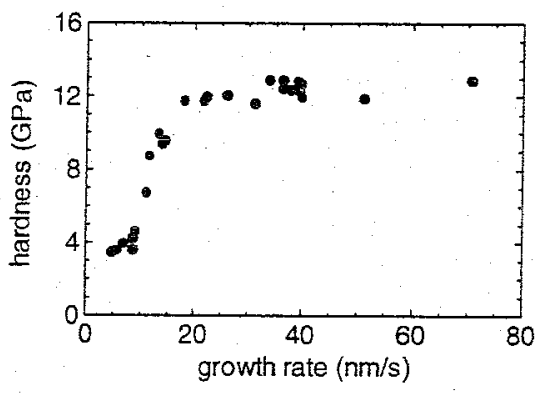

Figure 4 : The hardness vs. the growth rate.

\footnotetext{
J. Robertson, Surf. Coat. Technol., $\underline{50}$ (1992) 185.

2 Y. Catherine in Diamond and Diamondlike Films and Coatings, Ed. R.E. Clausing, NATO ASI Series B, 266, Plenum, NY, 1991.

3 J.W.A.M. Gielen, M.C.M. van de Sanden, P.R.M. Kleuskens and D.C. Schram, Plasma Sources Sci. Technol, accepted for publication. s.W.A.M. Gielen, P.R.M. Kleuskens, M.C.M. van de Sanden, L.J. van IJzendoorn, D.C. Schram, E.H.A. Dekempeneer and J. Meneve,

J.W.A.M. Gielen, M.C.M. van de Sanden, D.A.J. Wouters and D.C. Schram, to be published.
} 